\title{
Status of Communities Around Forests in Management of Forests Based on Regional Authority in the Order of Regional Autonomy (Study in Kalimantan Island)
}

\author{
Rusdianto \\ Lecture of School of Law Science Habaring Hurung Sampit, Central Kalimantan
}

\begin{abstract}
ION
RESEARCH on the Position of Communities Around Forests in Forest Management Based on Regional Authorities in the Context of Regional Autonomy (Study on Kalimantan Island) is carried out based on normative legal research methods . from search and analysis, that the management of foresdtry example contained in Law No. 41 of 1999 has progressed because regional authority over forest management is wider than the previous law. This is a manifestation of the increasingly greater authority given to the region to manage the forests in its area. In the management of the forest, there is a concern for the people and the management of the forest and the environment has been integrated. It this become an important part in the efforts for members of the Dayak and forestry accordance with the principles of the management of natural resources are limited. The community's rights in managing forests are protected and recognized so that forest management becomes part of the development of indigenous peoples. This condition is a proof of the respect of indigenous peoples for forests that are already dependent on forests for their potential for life. For it in order to involve the public on the responsibilities and benefits of management forestry, then the public about enforced Dayak late to get involved in the management of the forest. The empowerment of the community by always taking into account the integrative potential of the forest and its future development as a limited natural resource. For this role Concession rights holders Forests are very important in preserving the forest . It is the logging concessions that have great potential to exploit forests because of the complete infrastructure for this. Concession holders were members activities Dayak and forest must consider the condition of the forest, especially for the future. In this case, the integration of handling the problems that arise as a result of exploitation of forests is still not optimal. There are regional authorities which have not been properly implemented due to various regional limitations that are based on the limitations of human resources. In connection with the above, it is necessary to have a regulation that clearly explains the concept of forest management according to Law No. 41 of 1999, so that forest management is truly realized and can bring benefits to the environment and surrounding communities. For this reason, it is also necessary clarify the authority regarding forest management between regencies / cities and provinces. This is to prevent the overlapping of the exercise of authority held by the two institutions specifically with the existence of regional autonomy. Likewise, there needs to be a more concrete affirmation in the legislation regarding the rights of indigenous peoples to forests so that their involvement in forest management for Dayak and community members becomes evident. This is to prevent the continued domination of Forest Concession Rights (HPH) holders over the forest . There is a need for more concrete clarification regarding the implementation of government and provincial government and district / city government implementation by implementing empowerment properly. Here a more comprehensive arrangement is needed for regulations relating to the issuance of Forest Concession Rights (HPH) permits, which are located across regencies / cities where prior to issuance of permits, recommendations from the Regent / Mayor are required. In addition to the fundamental is the regulation that lays policy that regulate more clearly the implementation of the manager 's forests are in line with the Law number: 32 Year 2004 About Regional Government with all amendments thereto. Keywords: Indigenous Peoples; Forest Management ; Regional Autonomy.
\end{abstract}

DOI: $10.7176 / \mathrm{JLPG} / 93-12$

Publication date: January $31^{\text {st }} 2020$

\section{Preliminary}

Based on Law No. 32 of 2004 concerning Regional Government which explains the broad authority granted to regencies and cities, in practice it will still be limited by the authority of the central government as stipulated in article 10 paragraph (3) of Law No. 32 of 2004, namely : politics foreign affairs, defense and security, justice, monetary and fiscal, and religion.

In Article 13 paragraph (1) of Law no. 32 of 2004 states that the obligatory functions authority goverment provincial regions is a matter of scale provinces that include: planning and development control; spatial planning, utilization and supervision; implementation of public order and public peace; provision of general recommendations and facilities; handling the health sector; providing education and allocating potential human resources; tackling cross-regency / city social problems; cross-regency / city employment services; ko development facilities of Cooperatives, small businesses, and medium, including inter-district / city; 
environmental control; land services including cross regency / city; population and civil registration services; government general administration services; administrative services investor 's capital, including cross-district / city; the implementation of other basic services that cannot yet be carried out by the district / city and other mandatory functions mandated by laws and regulations. ${ }^{1}$

As for the Regency / City mentioned in Article 14 paragraph (1) of Law no. 32 of 2004 that mandatory functions which are the authority of regency / city regional government are affairs on the regency / city scale which include: ${ }^{2}$ development planning and control; planning, utilization , and supervision of spatial planning; implementation of public order and public peace; provision of public facilities and infrastructure; handling the health sector; organizing education; tackling social problems; services in the field of manpower; cooperative development facilities , small and medium businesses; environmental control; land services; population and civil registration services; government general administration services; capital investment administration services ; the implementation of other basic services , and other mandatory functions mandated by statutory regulations. ${ }^{3}$

In the explanation of the Act states that the Republic of Indonesia is rich in diversity of potential natural and non-biological natural resources, characteristics of cultural diversity of the people, and aspirations can be the main capital of National Development. For this reason, in order to achieve integration and unity of mindset and actions that ensure the realization of environmental management in an effective and effective manner based on Archipelago Insight, the Central Government establishes certain authority by taking into account the situation and condition of the region both natural potential and regional capability, to the existing central government apparatus in the framework of implementing the principle of deconcentration .

Based on RI law No. 25 of 2000 on the National Development Program (PROPENAS) 2016-2018 stated that; National development in the field of natural resources and the environment is basically an effort to utilize natural resources for the greatest prosperity of the people by taking into account the preservation of environmental functions and balance, sustainable development, economic and cultural interests of the local community, and spatial planning. ${ }^{4}$

The authority of the Government of East Kotawaringin Regency in the field of forest is in accordance with the activities and conditions of the forests in the Koatawaringin Regency.

Based on the above description, there are aspects of environmental management that are formally synchronized between the Center and the Regions. This synchronization is hierarchically illustrated in regulating legal products, starting from the central level to the regional level. However, there are still other components which are precisely the regional authority to regulate but not yet clearly regulated.

The lack of clear regulation is due to several factors which in essence are the limited ability to formulate laws and regulations that specifically apply to the regions. The limitation is especially in the field of Human Resources that can formulate normatively the existing potential, management and compatibility with other related problems. For this reason, it is deemed necessary to urgently formulate these provisions in Regional Regulations that are integrally in accordance with regional conditions and can be implemented consistently.

Regarding community empowerment around the forest, in this perspective, the authors take a study of traditional community groups that are closely related to forest management ${ }^{5}$ Humans have inhabited the forest forests of Borneo about 35 thousand years to adapt to the political and ecological changes. The cultures of indigenous peoples living in Kalimantan, for example, are collectively known as Dayaks who are then reduced by the Dayaks . At present there are more than 3 (three) million Dayaks with a population density of 14 (fourteen) people every per kilometers every square. ${ }^{6}$

\footnotetext{
${ }^{1}$ In a manner juridical arrangements by the Center is considered more effective and more efficient compared if taken care of by the Regions. Such an arrangement becomes a limitation of regional autonomy that separates the affairs of the Central Government and Regional Governments, and all of which are regulated in the Law and its elaboration

${ }^{2}$ Affairs which is an exception from the affair distance as the basis of kin Government The center authority is Region for its implementation. ${ }^{3} \mathrm{http}$ ://blogmhariyanto.blogspot.com/2015/11/pagianagian-governance-konkuren.html . it juridical with invited its Law No. 23 of 2014 on Goverment Regions, the Law Number 32 Year 2004 regarding Regional Government as already amended by Law Number 12 Year 2008 regarding the Second Amendment Law Number 32 Year 2004 concerning Governance D aerah revoked and declared invalid. (Article 409 of Law No. 23 of 2014) this has an impact on the division of governmental management between the Central Government and Regional Governments including the forestry sector.

${ }^{4}$ Ibid. that the classification of government affairs (article 9 uu no. 23 of 2014) consists of: absolute government affairs, are government affairs which are fully the authority of the central government . B erikutnya government affairs concurrent, is a government affairs yan g divided between the central government and the provincial and district / city. Concurrent government affairs handed over to the regions become the basis for the implementation of regional autonomy. At last government affairs public, is the government affairs under the authority president as the head of the environment and forestry, including in matters of concurrent administration

${ }^{5}$ There will be many Indigenous people in various region in the country. But for this study, the writer takes the example of the Dayak people in Kalimantan who traditionally live and continue to grow dynamically until now by not breaking away from the ecology of life in the form of forests. Another reason is that the collection of material about the Dayak community is relatively easier for writers to do.

${ }^{6} \mathrm{https}: /$ www.romadecade.org/suku-dayak/. The Dayak tribe is a tribe in Indonesia that inhabits the interior of Kalimantan. Primitive life and far from global information access is their characteristic. But starting from there, there is something interesting to know. One thing that is very interesting to learn is culture them. Dayak in language is actually not a name for a tribe. The term " Dayak people" in the Kalimantan language generally means " inland people", which they are far from city life. The call of " Dayaks" is not specific to one tribe, but various
} 
In a cultural perspective, the Dayak Indigenous people have many similarities even though there are many different ethnic sub-groups, social structures, traditions of government that are applied internally. But the difference does not reduce the nature of the emotional relationship that is very close to the community members and among tribal children in a wider social life. This reflects closely the historical roots that make them a unity in a shared life. ${ }^{1}$

\section{Map of Communities Around Forests in Kalimantan}

Pul au Kalimantan, in general, can be stated as a region that is rich or even very rich in Natural Resources (SDA). In physical language on this island there are large river springs and large forest areas, which are home to a variety of fish, more than 500 species of birds, many endemic species, almost unknown plants including more than 50 species of ramin wood (dipterocarpae) ) that the wood is very valuable, and the animals of endangered species, including the forests, and species of star another partially extinct and living in history. ${ }^{2}$

For centuries, Dayaks have depended on farming, fishing and hunting and gathering forest products and changing their priorities as the situation changed. As noted by Pad and Mukimin, the dynamism of Kalimantan people in utilizing natural resources must be understood in the context of a change that takes place continuously in the forest environment . Community sifter as well as the Europeans have to adjust their management agencies through drought, fire disasters, wars and population changes in an attempt to hi dup on earth Borneo.

Borneo (Kalimantan) is now occupied and inhabited by citizens of 3 (three) countries, namely Indonesia, Malaysia and Brunei Darussalam. In the region of Indonesia (collectively referred to as Kalimantan) is divided into several provinces, namely Kal imantan East, South Kalimantan, West Kalimantan, North Borneo and Kalimant 's Central. Each with a different area in the sense that some have the widest area (Central Kalimantan) and the narrowest is South Kalimantan.

Aktivit as political society Dayak so rapidly until the mid-1900 's in all three countries. After independence from the Netherlands, PPD ( Dayak Unity Party ) was formed and won the 1955 Elections in West Kalimantan. But in 1959, President Sukarno issued a regulation so that political parties have branches in 7 provinces. This disturbs relations between diverse ecosystem communities, in Indonesia and national politics under a single diversity. ${ }^{3}$

The above reality eliminates the strength of local communities which have not even grown to cover 7 provinces. Although all Dayak Indigenous peoples have laws and traditions, each Dayak sub-tribe has a difference in the process of creating and implementing these customary rules / customary laws.

Concern with law, then law Indigenous including the rules and procedures and division of property rights over land and forest. The composition of power is usually a group of adat leaders and their assistants. In some areas there are minor feasiasi with a government that unites several communities, anyone, including outside authorities, must obey the customary law in a community if it is within the village / community area.

Tracing the historical roots of society Dayak $t$ ersebut, and of course also other indigenous people who clearly understood that they are actually culturally have the right as assets existing life. This right covers various dimensions of life which include:

a. the right to a free life

b. the right to better welfare

c. the right to participation in social life

d. the right to manage available natural resources. ${ }^{4}$

Among the various fundamental rights, in the present perspective it is closely related to Human Rights whose existence is protected and obtained constitutional protection from the constitutional system. Various provisions which are of the highest law, whether in the Constitution or in various international conventions outline the existence of such rights as an inseparable part of universal human values. ${ }^{5}$

Very important means, specifically related to the legal aspects of community participation in natural resource issues is an understanding of their rights to shared life assets in the form of forests. In this connection it is understood that forests are indeed a common asset which is naturally a gift from God to a nation. Forest is a natural gift which is a very important commodity for natural survival of various types of flora and fauna life in a certain area.

Another very important aspect of efforts to reflect this in the forest problem is to provide an understanding that humans are accidentally born and raised around these assets. That they are very reasonable have different rights from people who do not live close to the forest area. This understanding is also strongly supported by the

tribes. For example, Dayak Kenyah, Dayak Tunjung, Dayak Punan, and dozens of other tribal children.

${ }^{1}$ Ali Akbar. 1999. Safeguarding the Wisdom of Lukal Indigenous Peoples . Pontianak: Dayak Society Study Institute. P. 13

${ }^{2}$ See: D. Sihite. 2000. Biodiversity in Indonesia. Pontianak: Dayak Community Study Institute, p. 23.

${ }^{3}$ Sarbaini. 1999. The Socio-Cultural Approach of Indigenous Peoples Welcomes a United Indonesia. Solo: Panepen Mukti p. 8 .

${ }^{4}$ Ali Akbar. Op. Cit. P 23

${ }^{5}$ Ibid. P. 34. 
Basic Law on Forests which provides a special place for community participation in forest management , especially the people who live and live around the forest .

In the rule of law, the people who live and utilize the surrounding forests as livelihoods are referred to as indigenous peoples. ${ }^{1}$ Indigenous people have a custom for generations, that is, naturally depend their lives on the natural assets that surround them. In order to improve their standard of living and preserve their lives, it is natural that they are given special rights to utilize available land, or take advantage of the surrounding forest with the limitation that what they are doing is within the boundaries support and realize the preservation of nature. ${ }^{2}$

Some of the concepts that are applied by indigenous peoples in their daily lives including the management of natural resources, especially the potential that exists in relation to forests are:

a. Ompik Bonuh: area used to build houses; this area consists of houses, gardens and baths usually on the river;

b. Rimba: old forest area, none of the agricultural practices that can be carried out in this area, members of the adat community with permission can collect building materials used for their needs, these materials are prohibited from being taken out or traded;

c. Tawang: a swampy area in which there are various types of grass used for weaving purposes and this area must be protected so that the community can collect weaving materials for household needs on an ongoing basis;

d. Dorik: a forested area on a hilltop, this area is protected to prevent landslides and protect water supplies;

e. Mih: cultivation area, there is also a smaller cultivation area than Mih called mpolai

f. Lobak: a swampy area that is used as a wetland agriculture area (paya or paddy fields)

g. Jameh: fallow or agricultural area

h. Domun: an area that has only once been turned into a field if it has been shaded 2 (two) times categorized as Domun Dodok.

i. Tembawang; a former residential area some distance from the village, planted with fruit and other productive plants. Usually, Tembawang is owned collectively. There is also Tembawang Pelaman which is a cottage or small house built for a group of people and hunters;

j. Agau; orchards in the forest. This area is open to anyone in need;

k. Keramat, this region which is sacred because in the region there are sacred objects or are believed by spirits in power in that place. This area will never be used either for fields or other purposes because it is strictly protected. Every year there is a traditional ceremony to request protection from the watchmen of the area for the peace of the whole community;

1. Podagi: a sacred place and object that contains totem poles ( Bukit Dayak buttocks ) this area is believed to be the abode of ancestral spirits, an area that is highly worshiped by the community. Every year a ritual ceremony is requested for blessings from the spirits in Podagi;

m. Pongharen: cemetery area

n. Kubon Ping: a river that is used for daily necessities including transportation

o. Balhe Ponodad: an area for the disposal of machetes and other weapons and agricultural equipment and household appliances made of iron. ${ }^{3}$

All of these concepts actually reflect the existence of a harmonious relationship between indigenous peoples and forests that are holistically alive, maintained and passed down through generations. Therefore, as long as its development is in line with broader interests, it can be applied in a statutory regulation as an inseparable part of efforts to realize forest sustainability in Indonesia. Thus efforts to preserve forests by accommodating the rights of Indigenous peoples will be realized as well as possible.

In connection with the empowerment of Forests by the People around the Forest, in the daily life of the Indonesian government does not respect the rights of indigenous peoples to their ancestral lands although legally recognizing these rights, the government has used and abused the clauses in the LoGA No. 5 of 1960 which states that the implementation of customary rights and similar rights from indigenous peoples as long as in reality there must still be such that it is in accordance with national and state interests. ${ }^{4}$

In the some cases, under the laws of the government to effectively divide the area for a number of logging companies, large plantations, transmigration land and forests - forests environment / nature reserve without consulting $\mathrm{m}$ asyarakat Peoples. This causes the community there to be helpless and affect their culture and lives. The longer the meaning and existence of the forest for them, the forest and the land they occupy since long time ago was completely cleared by laws and regulations.

People are worried $d$ ith a variety of programs that are shaded with various fanciful name with the name of Region Development of Economic Integrated (KAPET), a program that is planned so ideal for reducing the gap

\footnotetext{
${ }^{1}$ Sukamdani. 1988. Indigenous Peoples in the Perspective of Legal Anthropology. Jakarta: Indonesian University p. 45.

${ }^{3}$ Ibid. P. 52

${ }^{4}$ J. Kusni. 2000. Lessons From Dayak Communities. Pontianak: Institute of Dayakology. P. 128-129
} 
between eastern and western Indonesia. It seems that such a thing can alienate them from the life they have been enjoying in peace.

The KAPET program was inaugurated in 1996 based on President Suharto's decree. The program is aimed at developing oil palm plantations, mining (smelly ksit), rubber plantations, hybrids (opposed to natural rubber) and industrial timber companies (HPH and HTI). Even though a study conducted by JICA in 1996 concluded that the land was not suitable for oil palm but the KAPET program would actually build 3,2 million hectares of oil palm. It is difficult to argue that the KAPET program will encourage indigenous peoples to be increasingly excluded from their land. ${ }^{1}$

In the beginning of the construction program in 1962 the government had ordered all the long houses to be demolished because they were considered old, unhealthy and flammable and obstructed construction. The government encourages Dayaks to live in single homes. New villages were created and all regulations were made uniform. The Village Governance Act (Law No. 5 of 1979) devastated indigenous institutions and the functions of Indigenous community leaders. The government took the initiative and facilitated the establishment of Dayak's adat institutions and was regulated by forming Dayak adat councils in all sub-districts and districts, as well as Dayak adat assemblies at the provincial level.

In many cases, capitalist companies have repeatedly used these institutions to acquire and control Dayak lands and transform Dayak territory into large industrial timber and plantation estates (saw it, rubber, superior rubber, cocoa and hybrid coconut) Large companies supported by the government utilize the customary institutions for their interests.

The Dayak Indigenous Peoples have lived in Kalimantan long before the Republic of Indonesia was formed. They life with customary rules, institutions of Indigenous and has a continuous management SDA system. People Dayak have ties buda yes very strong with forests and have practiced management system huta $\mathrm{n}$ wisely for centuries. The original wisdom has recently been revived through the participatory mapping process. Dayaks naturally nurture knowledge about sustainable management of natural resources. ${ }^{2}$

The rotational system of cultivation is done in the next 5-15 t cope in an area. After harvesting the fields will be planted with rubber trees, fruits, rattan, etc., if the land in the former land is no longer suitable for planting the following year. After rubber, fruit, rattan are no longer productive, then a real will be served again and this means that the land is fertile again.

System resource utilization forests by communities Dayak Airity principle of sustainable, family, collective and customary law. This reflects the pattern of empowerment that be $r$ nature of holistic wherein the various components of a good life that relate to his fellow citizens in the community and do den gan obtain a harmonious nature. Circumstances that are on a more universal scale are also used as a guideline for traditional communities in various countries, especially in third world societies which are largely in the traditional order of life .

Forests and their products are important, and different forest areas are managed intensively enough to share yields through natural forest enrichment. Indigenous Dayaks use forest products as a source of livelihood. For example a typical Dayak community uses around 200 species of plants from the forest for medicine. Ritual offerings or lack of fruit yields show the importance of the principle of sharing and exchanging for good. The Dayaks see fruit harvests as an indication of the quality of the relationship between humans and humans and nature. Because many local fruits are species that produce based on a certain time (once a lot of fruit, a few years later there are none). Small yields for several years are a warning to residents about their relationships with others. ${ }^{3}$

Over a long period of time a large number of commercial plants have been planted in the forest. Various local fruit lots harvested from the forest people Dayak and sold to cities with high market value. Other local plants that are produced commercially include rattan, resin, valuable seeds. There are several types of plants that are not local but also valuable products .

In the 1990s the natural rubber was introduced and planted to forest - forest communities Dayak . The production of the Dayak community rubber plantations is a major contributor to the world's rubber. Unlike the superior rubber in which there are only rubber trees, in the natural rubber tree there are also other types of plants for the purpose of life ,. The Dayaks are very careful in maintaining a balance between economic dependence on forest products and rice production as a livelihood - a balance between maintaining a forest ecosystem or turning it into a plantation area.

For the Dayak tribe farming is a must. Most Dayak rituals are related to farming. Rice has a spirit that must be nurtured and respected through good field management. This trust supports the ongoing and dynamic development of the cultivation system so that the eco system remains sustainable, especially to realize the preservation of forests as a place where they live, try and hang the lives of the next generation. ${ }^{4}$

\footnotetext{
${ }^{1}$ Basri Usman. 2001. Local Wisdom of Indigenous Peoples . Salatiga: Universitas Satyawacana. P. 34.

2 Ibid. P. 50.

${ }^{3}$ Ibid. P. 60.

${ }^{4}$ Ibid. P. 67.
} 
At present the HPH and HPHH concessions have covered the Dayak community forests and these concessions have caused severe ecological damage. Only about 4 percent of all concessions actually follow ecological rules. At the beginning of the reform period in 1998 there was the demand that the state revoke the status of forest countries to redefine the boundaries between forest ne because with less forest that has been owned and managed and controlled by the original or tradision al by the local community. ${ }^{1}$

Revoke all provisions and policies relating to exploitation and violation of the community's right to manage natural resources responsibly. But the Basic Law to the Forests (Law No.41 of 1999) failed to bring meaningful changes to the situation, except only as a basis for adat and its people as a form of false respect.

The change above is evidence that the movement has begun to gain support and the authorities have relented. People are still being forced to accept the rights offered by concessionaires except they can gather the masses in action in unity to reject Eksplo itasi woods that hide behind the modern technology but basically would damage the forest .

Therefore, the pressure began only recently, in general society shortage original ways to recognize and follow up on various programs pele starian forest. Active adjustments require awareness of the issues that arise. Community groups generally do not know the boundaries of their forest areas from coercion by forest concession holders. They agreed to expand the forest area which is actually owned by indigenous groups.

Lack of ignorance about the boundaries of their area or village also causes ignorance of the participation that should be expected of them. This is what needs to be emphasized so that their participation can truly be synchronized in a holistic building for community-based forest management for the preservation of the forest itself in the future.

Thus the preservation of forests can be realized not only at the insistence of formal rules particularly from the Government of Pakistan tah nevertheless precisely center of communities living around the forest to bring awareness that it has a positive value for them and their generation will datang.Adapun directions policy activities in the field of protection of forest and nature conservation for the years 2008 - 2009 milsany a, set by the government, namely:

1. The management of conservation areas and protected forests is strived to improve the welfare of local communities and increase state revenue. Management priorities are directed towards being able to develop and utilize the potential of flora, natural attractions and clean water sources

2. The management of conservation areas and protected forests when the country is facing an economic crisis, is prioritized for productive and labor-intensive activities. These activities include the creation of tourist trail roads, maintenance of regional boundary lines and multipurpose plants.

3. Development of pilot units for breeding fauna and flora and enhancing community development. Fauna breeding activities directed to produce proteins and industrial material, pet animals such as deer, chicken forests in Bali and Java. Furthermore, to develop flora cultivation, efforts will be made to cultivate ornamental plants (including flowers), orchids, medicinal plants and industry.

4. If in a province there are many conservation areas, it is necessary to determine priority locations to be handled first. Determination of priority location needs to pay attention to the availability of existing human resources.

5. In order to increase the security of forest production, the government demanded the responsibility of the concessionaires / HPHTI to dap at independently responsible for securing the area huta $\mathrm{n}$ and potential.

6. To reduce the rate of forest encroachment, the circulation of illegal forest products, destruction of corals, logging, the effectiveness of rangers will be increased, in addition to recruiting 1,500 new rangers.

7. Early prevention of forest and land fires will be increased so that fire control measures can be carried out quickly and thoroughly. In order to get early information about the occurrence of kebakara, the use of Satellite Imagery in monitoring the Hot Spot as a matter of course needs to be done in the field checking and blackout action.

8. Effective implementation of AMDAL provisions, especially those relating to management and monitoring (RKL-RPL / UKL- UPL) in every forest activity . ${ }^{2}$

\section{III . Role Holders of $\mathrm{H}$ ak Forest Concessionaires Me preserve the function of forests}

From series of provisions concerning the necessity to preserve the function of forests, both issued by the Central Government shows the strategic role of the concessionaires in preserving the function of the forest . This is understandable given that it is HPH holders who exploit large numbers of forests and large areas. ${ }^{3}$

Are nominally, the Government has issued a lot of provisions that are closely related conservation efforts Fungs $\mathrm{i}$ woods yan $\mathrm{g}$ closely linked with the role of the concessionaires in the preservation of forest. Among the important and directly related to policies to preserve the function of the forest is in the prevention of damaging

\footnotetext{
${ }^{1}$ J. Kusni. Op. Cit. P. 70

J. Kusni. Op.cit . P. 76.

${ }^{3}$ Ibid.
} 
the forest with legal instruments. In addition to the provisions mentioned above, hierarchically, the provisions regarding the participation of $\mathrm{HPH}$ entrepreneurs in preserving environmental functions can be referred to in Law No. 23 Year 1997 concerning Management of the Living Environment. It is stated in article 15 paragraph (1) that every business plan and / or activity which is likely to have a large and significant impact on the environment, must have an Environmental Impact Assessment (AMDAL).

This AMDAL is a planning instrument for assessing the feasibility of a business whether it is environmentally feasible, so that the consideration is not solely based on mere economic or technical feasibility. This AMDAL is also a licensing requirement, so that an activity includes an operation, which according to the AMDAL mandatory requirements, but which does not prepare an AMDAL, the permit may not be issued.

Provisions regarding business plans and / or activities that have a large and significant impact on the living environment as referred to in article 15 paragraph (1), as well as the procedures for preparing an AMDAL assessment are stipulated by a Government Regulation. The Government Regulation referred to is No. 27/1999 concerning AMDAL. Specifically in the forest and plantation sector, in order to minimize the environmental impacts that occur due to forest exploitation activities

For the purposes above, as a policy implemented in writing, the Government has issued a Ministerial Letter to the Forest and Plantation No. 602 / Kpts-II / 1998 jo No . 622 / Kpts-II / 1999 concerning AMDAL, UKLUPL Forest and Plantation Development. With this regulation, it is expected that activities carried out in forest exploitation that are suspected to have negative impacts must be regulated as early as possible . Exploitation forests must be adapted to the carrying capacity of natural resources, especially resources of forest and sustainability can be assured.

Of course, not all businesses and / business plan activities including forest exploitation (HPH) are required for AMDAL, but only for activities that have a large and important impact. To review which business and business plan activities are required for AMDAL and which are not required for AMDAL, the government through the Decree of the State Minister of Environment / Bapedal has issued Decree of the State Minister of Environment No. Kep. 17 / Me nLH / 5/2001 concerning Types of Business or Activities that must be completed with AMDAL. As for businesses or activities (including forestry fields ) that are not required for AMDAL, as stipulated in article 3 paragraph (4) Government Regulation No. 27 of 1999, must undertake Environmental Management (UKL) and Environmental Monitoring Efforts (UPL).

Thus the participation of HPH entrepreneurs in preserving forest functions has actually been encompassed with the obligation to prepare AMDAL or UKL-UPL. Because in document A MDAL itself, besides containing AMDAL (Environmental Impact Analysis), there are also documents called RKL (Environmental Management Plan) and RPL (Environmental Monitoring Plan).

Therefore, in the preparation of the EIA document the employer field aan forest, closely related to certain of the functions of protection forests which are operationally starting from the Law until the bottom of the legislation. All of these provide a picture of the seriousness of the government in managing the forest problem with all its potential and consequences.

The series of statutory provisions mentioned above forms the basis for every HPH permit holder to carry out their obligations in preserving forest functions. How is the real participation of the HPH permit holder in preserving forest functions, as stated in the AM DAL or UKL-UPL document, it must be known in advance what activities or activities carried out by the HPH permit holder in the implementation of forest exploitation activities .

From the description of their activities, there will be an impact on the environment so that starting from here, HPH permit holders can contribute to participate in preventing, controlling and overcoming environmental problems as a result of their activities in forest exploitation. This is a real implementation of the commitment of the concession holders in participating in preserving forest functions as stated in Article 32 of Law No. 41 year 1999 which states: HPH permit holders are obliged to maintain, preserve and preserve the forest where they operate.

Taking a closer look, the HPH activity plan carried out by the HPH permit holder will consist of several stages of activities, namely:

a. Forest Utilization Plan
a. Clearing of forest areas
b. Making Base Camp / base camp
c. Timber crusing
d. Logging $^{1}$
e. Logging from the felling block to the collection site
f. Transporting timber from the TPK to the log
g. Making TPK, Logpond and dock

${ }^{1}$ Ibid. P. 78. 
h. The activity of dividing the brick, hindering and preserving wood

i. Timber assembly and transportation activities

From the series of activities mentioned above there are certainly activities that have an impact on the forest environment . At least the activities of the construction of the angkuta road and logging and skidding plans have an impact on the forest ecosystem .

In the activity of making transportation roads will open forest areas so that it will cause many important impacts such as erosion, sedimentation, changes in soil permeability, and decreased diversity of aquatic biota.

Furthermore, as a result of logging and skidding activities, wood structure will deteriorate, decrease wood potential, change land cover and disturb the presence of wild animals. Besides logging and skidding activities can also cause secondary, tertiary and subsequent impacts such as erosion changes, sedimentation, climate and others. Another impact that arises is the emergence of negative public perceptions with the presence of HPH.

\section{b. Forest Development Plan}

In the forest development plan, HPH permit holders will carry out development activities which include:

a. Maintenance of remaining stands

b. Making nurseries or collecting seedlings

c. Planting or enrichment plants

d. Maintenance phase I and maintenance condition forestry

From some of the activities at this stage of forest development, possible impacts arise from the activities of the stand clearing, maintenance of stands, planting and enrichment.

\section{c. Forest Protection and Security}

Activities within the framework of protection and security of forest that includes:

1)Fire Fighting

2)Safeguards against theft of forest products and illegal logging

3)Prevention and control of shifting cultivation

4)Pence Gahan and prevention of encroachment of forest

5)Prevention of erosion

\section{d. more activites}

Other activities in the context of implementing forest exploitation (HPH) include activities such as:

1. Mobilization of equipment and materials

2. Employment

3. Development of social facilities and infrastructure both for employees and the surrounding community and the forest village community development program (PMDH)

From this stage of activity, what is fundamentally affecting environmental change is a workforce absorption plan and a rural community development program.

Workforce absorption activities include recruitment and procurement of labor both locally and from outside the region, this is due to the existence of base camp and logging development activities. The procurement of labor is estimated to have an impact on the socio-economic and cultural sub-components.

As a result of this activity visible changes to the socio-economic and cultural sub-components include: population growth, changes in employment opportunities, changes in approach, institutional arrangements, changes in community perception and so on.

\section{IV . Patterns Empowerment and Participation of Society d i Neighborhood Forest in the Management of Forests}

The study of community participation ( public participation, public involvement ) can be understood and defined differently. Differences in defining and understanding community participation can occur because talking about participation actually will talk about the distribution of ions of power ( power distribution ) from the state to the people.

In terms of the power holder (government), there is certainly a desire that this community participation does not undermine his power wherever possible. This strong will will clearly influence the product of the policy of the state in a country. On the other hand pro-democracy forces (in the current context may be more appropriate: " pro-reforms) want that community participation is the process of distributing power so that the state (especially government) is not dominant (because if it is too dominant there will be no mechanism check and balance ).

Unlimited power can lead to abuse of power ( abuse of power ). From this contradictory desire, it can be imagined that talking about community participation will be in the interests of interest and not a sterile area of political problems.

Recognizing that community participation is closely related to the issue of power, some political experts, other social sciences, law, planning and the environment define categorical community participation such as: Sydney Verba (1972), which sorts society's role into pseudo participation or partial participation on the one hand, with democra tic participation or influence participa tion and full participation on the other side. 
The first category describes community participation which is nothing more than community mobilization to support programs that have been unilaterally determined by the government. While the second, is the process of community participation that provides opportunities for the community to influence decision making regarding the lives of the community itself. ${ }^{1}$

Based on the sorting of the types of community participation as mentioned above, it would be clear that a country which is not or less democratic, will flourish the type of participation that is psedo, non- participation will flourish and vice versa. Therefore in this paper, it assumes that the role of the community is essential, that is, the role that really puts the community as the party that determines the policies in this case the preservation of forest functions

Today, the role of the community in Indonesia, especially in the preservation of the function of the forest, is very important. This is not only stated because the current reforms that have increased the bargaining position of civil society towards the state which for more than 30 years have been under the shadow of the authoritarian state power . But even more essential is that the community does have a role in determining forest resource management policies in the area.

In addition, the right to participate is one form of recognition of public rights to regulate the administration of the state (political rights) and rights to participate in enjoying natural resources (economic rights). Rights this right other than recognized in some ketent uan existing laws, has also been confirmed in dekl Arasi Rio de Janeiro (the result of the Earth Summit) about democratization in decision making (principle of the 10th) and community participation in the implementation of the principle of sustainable development ( principles 19, 21 and 22). More than that community involvement is a measure of whether there is public accessibility in a democratic political system.

In the context of state administration policy, the role of the community is always debated not only because there is a political need, in the sense of fulfilling the standards of legitimate policy procedures, but also because the dynamics of society do require a continual expansion of roles according to the context of social change. Therefore, it becomes very naïve to meet the demands of the needs of the role of the public always simplified to be a matter of " information delivery" or " socialization" of a mere policy. ${ }^{2}$

The problem is, how is the role of the community in conservation Fungs i forest ? juridically formal, there are various provisions of legislation governing community participation in the preservation of the function of the forest .

Hierarchically, the legal basis for community participation in environmental management can be seen in the provisions of Law No. 23 of 1997 concerning Environmental Management. Article 6 (1) states: Every person is obliged to maintain the preservation of environmental functions and prevent and cope with environmental pollution and damage. ${ }^{3}$

In the explanation of article 6 (1) it is stated that the obligation of each person as referred to in this paragraph is inseparable from his position as a member of the community which reflects human dignity as individuals and social beings. This obligation implies that every person participates in efforts to preserve the environment. Included in this context, of course, is everyone's obligation to help preserve the function of the forest .

Furthermore, in article 7 (1) of Law No. 23/1997 emphasized that the people have the same and broadest opportunities to participate in environmental management. As stated in paragraph (2), the role of the community can be carried out by: ${ }^{4}$

a. Increasing independence, community empowerment and partnerships. Because the independence and empowerment of the community is a prerequisite for growing the ability of the community as actors in environmental management together with the government and other development actors .

b. Growing the ability and community leadership. Because this will increase the effectiveness of the role of the community in environmental management.

c. Foster community responsiveness to conduct social supervision 1. Because that way it is expected to further reduce the possibility of negative impacts.

d. Providing opinion suggestions

e. Deliver information and / or submit reports

What was stated above is a general provision regarding the role of the community in protecting and

\footnotetext{
J. Kusni. Op. Cit. P. 82.

${ }^{2}$ Activity from PT. Bina Alam Indah Lestari (Main Report).

${ }^{3}$ Sydney Verba, as quoted by Mas Achmad Santosa, The Role of the Community and Information Openness in Environmental Management, Paper presented at the Executive Training on Preparation of the Environmental Impact Management Program in collaboration with ProLHBAPEDAL, Jakarta Dec. 1999 p.2.

${ }^{4}$ Suwiryo Ismail, 1999. " Strengthening the Role of Communities in Natural Resource Management and the Environment in the Regions", Paper Presented at the Training on Preparation of Environmental Impact Management Program in collaboration with ProLH-BAPEDAL, Jakarta Dec. 1999 p.2.
} 
preserving the environment which can actually be analogous to maintaining and preserving the function of the forest as part of the environmental element. In particular, the role of the community in the problem to the forest an is regulated in Law No. 41/1999 abo ng Into the woods late and its implementing regulations. In the consideration for letter $\mathrm{C}$, the Law states that sustainable and world-wide forest management must accommodate the dynamics of aspirations and community, customary and cultural participation, as well as community values that are based on national legal norms.

Furthermore, in the body part of the Law on the issue of community participation, they get a special place, namely Chapter IX and Chapter X. Chapter IX provides a place for the existence of indigenous peoples in relation to the forest issue .

Article 67

(1) states: Indigenous and tribal peoples insofar as in reality they still exist and are recognized as having the right to:

a. collect forest products to meet the daily needs of the indigenous peoples concerned

b. carry out forest management activities based on existing customary law and not in conflict with the law and

c. get empowerment in order to improve their welfare

(2) The affirmation of the existence and elimination of the customary law community as referred to in paragraph (1) shall be stipulated by a Regional Regulation.

(3) Further provisions as referred to in paragraph (1) and paragraph (2) shall be regulated by Government Regulation.

What is the general role of the community in this matter to the forest, regulated in the body of Law No. 41/1999 Chapter X. Articles 68, 69 and 70. Article 68:

(1) The community has the right to enjoy the quality of the environment produced by the forest

(2) In addition to the rights referred to in paragraph (1). community can not:

a. utilize forests and forest products in accordance with applicable laws and regulations.

b. knowing allotment plan forests, utilization of forests, and information to forest an

c. provide information, advice and consideration in pembang unan to the woods early and

d. to supervise the implementation of development to $h$-utan 's direct or driving directing.

(3) Communities in and around the forest are entitled to compensation due to loss of access to the surrounding forest as a work field to meet their living needs due to the determination of forest area, in accordance with applicable laws and regulations.

(4) Everyone has the right to compensation from the loss of his property rights as a result of the determination ka wasan forest in accordance with the provisions of applicable law.

Furthermore, community participation is regulated in Article 69.

(1) The community is obliged to participate in maintaining and protecting the forest area from disturbance and destruction

(2) In carrying out forest rehabilitation , the community may ask for assistance, service and support to nongovernmental organizations or other parties or the government; Other provisions governing community participation are contained in article 70:

(1) mobition of have participated in the development in the field to the woods early

(2) The government is obliged to encourage community participation through various activities in the field of forestry that are efficient and effective

(3) In order to enhance public participation, government and local governments may be assisted by observers forum to the jungle an

(4) Further provisions as referred to in paragraph (1) and paragraph (2) are regulated by Government Regulation. In addition to the articles stated above, there are other articles that give authority over community participation in forest management, such as article 34, which states that for the management of forest areas for special purposes can be given to indigenous peoples. Likewise forest use is carried out by the relevant customary law community in accordance with its function, as stated in article 37.

Furthermore, to ensure the best implementation of forest protection, the community is involved in forest protection efforts as affirmed in article 48 paragraph (5).

In the case of Community Participation in connection with Forest Concession by the holder of Forest Concession Rights, that in the past the shadow of the Indonesian people about tropical natural forests in Indonesia was haunted by a number of spirits that were frightening and there were still many wild animals roaming around. Overview of the state of forests such that result in population less dare disturb the existence of the forest. To cut down just one tree, it must often be accompanied by a sacred ceremony, as one of the conditions (based on the belief they believe) so that the cutting down of the tree does not cause havoc or bring disaster.

But since enactment Law No. 5 of 1967 which was later updated with Law No. 41 of 1999 concerning 
Forests, the human picture of the forest turned into another, in which the forest with the value of wealth contained therein seemed to be a " gold mine" in the form of the wealth of a very high-value tree species. ${ }^{1}$ How clearly the presence of the above Act have been able to reveal the dark as well as opening new horizons will be forest to start digging and picking up the results as much as possible. Shadow spooky myths and stories tentan $g$ forest can finally breached with advances in technology and modernization tools that can work in a variety of state forest . Areas of forest that previously received less attention began bustling enforced i limit ownership by flags Forest Concession Rights (HPH).

The above is indeed possible because Law No. 41 Year 1999 has set the arrangement of forests in a way that allows for obtaining maximum benefit from the presence of hu tan. Article 22 of the law, for example, has governed forest governance and the preparation of its management plan. Forest governance is implemented in the context of more intensive forest area management to obtain more optimal and sustainable benefits.

Activity of governance forests include the efforts of the division area for utilization of the forest . The blocks are divided into plots based on management intensity and efficiency. Based on the distribution of blocks and plots, a forest management plan is then arranged for a certain period.

With regard to the use of the forest itself, article 23 of Law no. 41 Year 1999 has provided opportunities for the utilization of forest $d$ ith the purpose result optimum benefit to the welfare of all the people equitably while maintaining sustainability, as stipulated in article 23 of Law Into the forest 's No. 41 Year 1999. Utilization of the area of forest that can be done in all areas of hu tan except in forest nature reserves and core zones and wilderness zone in the national park, as stated in article 24.

As stipulated in article 6 paragraph (1), that forests have three main functions, namely: conservation functions, protection functions and production functions where these functions are determined by the Government, the government also regulates how to utilize these forest functions . Article 26 paragraph (2) regulates the use of protected forest which is carried out through the granting of a business license for the utilization of the area, a business permit for the utilization of environmental services and a permit for the collection of non-timber forest products.

For area utilization business permits, it can be given to individuals and cooperatives. Permit for the utilization of environmental services, can be given to individuals, cooperatives, national private-owned enterprises and also state-owned or regional-owned enterprises. While the collection of non-timber forest products in protected forest areas can be given to individuals and cooperatives.

For the utilization of forest production, has been arranged in chapters 28 and 29. Utilization of forest production that could be area utilization, use of environmental services, utilization of hu tan wood and non-wood, and harvesting of forest timber and non timber. As with the use of protected forests, the use of production forests is also carried out through the granting of business licenses for the utilization of the area, permits for the utilization of environmental services, business licenses for the utilization of timber forest products, permits for non-timber forest utilization, permits for collecting timber forest products and permits for collecting non-timber forest products.

Permit for utilization of forest area and collection of timber and non-timber forest products in production forests can be given to individuals and cooperatives. Meanwhile, to permit utilization of the service environment, the results of the forest is not timber and forest wood in forest production, can be given to individuals, cooperatives, an Indonesian private-owned enterprises and state-owned and state / region.

Exploitation of forest is one of the activities in pe mbangunan forest. Besides the exploitation of forests , the development activities of forest consisting of: managing watersheds (DAS), rehabilitation of degraded lands, reforestation, construction of zoos, safari parks development and so on. Forest exploitation (H PH) itself, so far there have been known several kinds such as industrial timber plantation concessions (HPHTI), sago forest concessions (sago HPH), bamboo forest concessions (Bamboo HPH) and so on.

Forest exploitation is a sector that carries out natural resource utilization activities so that when viewed in terms of revenue, the presence of HPH entrepreneurs is really a very encouraging thing because with the development of the HPH the sector to the forest has been able to place it as a foreign exchange supplier in number two after oil and gas. ${ }^{2}$

The existence of forest exploitation activities also brings benefits not only to the holders of their own HPH licenses but also to the government and the community. As for the usefulness for entrepreneurs PH PH between others as follows: ${ }^{3}$

\footnotetext{
${ }^{1}$ Koesnadi Hardjasoemantri. 1997. The Relevance of Developing a Partnership Approach in Complaints and Complaints Resolution in the Environment, Paper presented at the Workshop on Community Complaint Management and Dispute Resolution Systems in the Kalimantan Environment Sector, in Samarinda on 8-9 April 1997 Cooperation of the Ministry of Home Affairs, Office MenLH, Bapedal, Local Government of East Kalimantan, ProLH Kalimantan and ICE

${ }^{2}$ Soenarno et al, 2013. Indonesia's Selective Logging System and Possible Applied Pathway / Cell Model in Tropical Forests, Jakarta: Center for Forest Product Research and Development of the Ministry of Forestry.

${ }^{3}$ Ibid.
} 
1. Cultivating wood on an on going basis with species that meet the requirements according to the provisions of the Indonesian Selective Cutting and Planting System (TPTI.).

2. Carry out forest development by carrying out replanting in a real / empty / damaged / logged-over area or carrying out maintenance in the logged-over area in accordance with TPTI regulations.

3. Providing seedlings for safe and enrichment activities by building strong nurseries, so that the number of seeds available in sufficient quantities and good quality.

4. Carry out community development activities through the Development of Forest Villages (PMDH) to villages included in the area of the HPH of the entrepreneur concerned. ${ }^{1}$

With the presence of HPH, the community can also reap benefits, among other things:

1. Increase business opportunities and work opportunities, due to forest exploitation activities

2. Increase the accessibility of roads, due to the presence of HPH roads

3. Increasing community income, because local economic facilities will increase, for example the existence of markets, the development of stalls / shops and the presence of motorcycle taxis.

As for the Government itself, the presence of HPH will also bring benefits, namely:

a. To help Government in managing the resource forest, so as to generate income.

b. Help the government accelerate the development of a local area.

But on the other hand, forest exploitation can also cause environmental damage . So that the damage does not worsen, the utilization of forest resources must be environmentally responsible, so that long-term sustainable use of the forest is expected. That is, forest development policies are needed and their use must be carried out to support the national economy without having to forget the ecosystem of the forest itself.

To control forest damage and the environment of the forest area , the Government has issued a policy in the sector to the forest as outlined in the General Forest Plan (RUK) which is used as a basis for compiling plans for the forest and is a guideline for forest development . and as a communication tool within the forest sector itself and with other sectors.

The policy adopted is to divide the forest area based on its function as outlined in the form of the Forest Enforcement and Administration Plan (RPPH) or better known as the Forest Use Agreement (TGHK). Ketent uan this in practice coordinated with the Provincial Spatial Map (RTRWP) which then dik ENAL with a map of the Land Use Forest (TGH), which is an integration of the TGHK and RTRWP. ${ }^{2}$

In general, the Government has also issued ketent uan governing the stewardship of forest in Indonesia, which has been allocated forests - forests that are allowed un tuk produced and forests - forests that should not be carried out production activities. Besides that, in production forests, not all vegetation that is contained therein is allowed to be cut down and in the previous logging plan, the area / area which may be cut and which may not be felled is determined in advance . For example, right and left of the river, the area around the spring, the border of the beach, the vasi concert area and so on in accordance with the applicable laws.

In the framework of the management of the hut late prod uksi Government in this case the Department of Into the woods early and Plantation also has established a policy to implement the silvicultural system are siste $\mathrm{m}$ cultivation of the forest or farming techniques forests starting from seed selection, manufacturing plants, until harvesting or logging since 1973 which was later refined with the Indonesian Selective Cutting and Planting System (TPTI) in 1989, then revised again in 1993. In this system must pay attention to the principles of sustainability huta $\mathrm{n}$ which include: sustainable production, preservation of soil and water, plasma nuftah protection, silvicultural techniques appropriate to the conditions ling kungan, composition and structure of the forest, growing properties and other types of trees.

Still in the context of forest concession policies, the Government imposes HPH holders to play a more tangible role in fostering communities in and around the forest by implementing the Forest Village Community Development program . The point is an effort to help improve the welfare of the people who are in and around the forest in addition to improving the quality of forest resources . ${ }^{3}$

In-Law - un dang No. 41 of 1999 concerning the right to community participation is mentioned in article 68 which has a meaning.

1. People have the right to enjoy the environment produced by the forest .

2. In addition to those referred to in paragraph (1) the public can:

\footnotetext{
${ }^{1}$ Ibid.

${ }^{2}$ Soemarsono, 1998. Policy of the Ministry of Forestry and Estate Crops in Managing Environmentally Friendly Development, Paper presented at the 1998 Regional Environmental Management Stabilization Working Meeting, August 21, 1998.

ANDAL HPH document (main report) PT. Bina Alam Indah Lestari South Kalimantan, pp. 1-19

${ }^{3}$ https: // foresterac t.com/characteristics-resources-forces-forests-and-facts-management/ . In this connection Forest resources are renewable resources with important conditions that you need to know about. Natural resources consist of renewable natural resources such as forests and non-renewable natural resources such as mining. Forest resources included in renewable natural resources must be understood more deeply about the characteristics of biodiversity ( biodiversity) as well as the interaction between biological elements and non-biological elements commonly referred to as ecosystems.
} 
a. utilize the forest and the results of forest accordance with the regulations - regulations that apply;

b. know forest designation plans, utilization of forest products, and information to forests ;

c. provide information, advice and considerations in forest development, and

d. mela kukan pengaawasan on the implementation of the Development into the woods late either directly or indirectly.

3. Community within and sek ITAR woods entitled to compensation for the loss of access to forest surrounding s sa employment to meet their needs as a result of the determination of the area of forest, according to the legislation in force.

4. Every person has the right to get compensation because of the loss of his rights to his property as a result of the establishment of the forest area in accordance with the provisions of the applicable laws and regulations.

While article 69 of Law - Law No. 41 Year 1999 regarding the fairness of the role of the community in the management of forest and determining;

a) The community is obliged to participate in maintaining and protecting the forest area from gannguan and destruction;

b) In carrying out forest rehabilitation, the community can ask for assistance, service , and support from other non-governmental organizations, or the government.

Implementation of empowerment by Law - Law No. 41 of 1999 is elaborated by Government Regulation No. 6 of 1999 concerning Forest Exploitation and Collection of Forest Products in Production Forests . Then it was clarified again by Minister of Forestry and Plantation Decree No. 318 / KPTS-II / 99 concerning community participation in forest exploitation which among others determines $:^{1}$

a. The purpose of community participation in forest exploitation. Increasing the participation of masyara kat perencanaanke in the field of forest late, so the implementation of the utilization of forest can be orderly and more democratic in accordance with the principles - principles of justice and equity.

b. Growing and realizing forest exploitation planning based on aspirations, and desires of all related parties;

c. Creation of community empowerment on social change through active community participation in forest planning;

d. Accommodate information and advice in planning forest exploitation ;

e. The realization of well-being and establishment of security of forest in spontaneous through the expansion of job opportunities and business opportunities in the segment - the segment of exploitation activities the forest .

The targets of community participation in forest exploitation are :

1) The community is openly aware of all forest designation and use plans .

2) Reducing the conflict between the parties - related parties, among others HPH / HPHT on the one hand with community on the other so that the management of forests with sustainable can be achieved.

3) Availability of a vehicle for resolving conflicts that are fair and balanced if individual property rights and the rights of indigenous peoples cannot be resolved between the concessionaire and the community.

The role of the community in exploitation forests based on the principle - the principle of as follows:

a. local communities are an inseparable part of the production forest exploitation system .

b. The local community is one of the entrepreneurs in the production and production of forest exploitation systems

c. Local people as economic exploiters are the same as other actors (private / BUMN / BUMD) in forest exploitation activities .

d. The existence of a mutually beneficial relationship between HPH / HPHT holders with the community.

Consesion holder HPH and Rightsholders Employers Forest Plants (HPHT) in preparing the development plan of the community around the forest (PMDH) involving the public and parties - related parties. In this connection, the community has the right to give consideration and enter information in the preparation of forest exploitation planning .

If there is disagreement between the community and concessionaires or HPHT in preparing the plan referred to in pa sal 5, people can memajuk an keberataan to the Head Office of the Ministry To forestry and plantations that the ransom was delivered to the Head Into the woods late provincial, local Provincial and the relevant HPH or HPHT holder.

Communities are obliged to respect and obey forest exploitation activities based on the agreed participation planning results. Provision of community opportunities as referred to in article 8 shall be carried out in the form of prioritizing work opportunities and business opportunities by HPH holders and HPHT holders to local communities both individually and in groups.

\footnotetext{
${ }^{1}$ Ibid.
} 
Employment opportunities for individual people are carried out in the form of recruitment of company workers, both permanent and daily workers according to their abilities and skills.

Business opportunities to the community in the form of employment in the activities of exploitation of forest that includes awareness, debarking, assembly, and other plantings - another through small business or co dispersions society with perjaan jian cooperation.

1. To carry out community participation in forest exploitation activities, each HPH holder and HPHT holder must prepare a plan for community participation.

2. Preparation of the plan referred to in paragraph (1) shall be based on the results of joint deliberations between the companies holding the HPH and the community, which are carried out one year before the forest exploitation activities as outlined in the proposed annual work plan or part of the annual forest concession .

In carrying out the activities of the participation of the community HPH Holders and HPHT Holders, must:

1. Providing funds in implementing work agreements is given to the community.

2. Make a detailed plan in the form of an operational plan based on a public knowledge plan .

3. Make a report on the implementation of community participation every quarter (four times a year)

4. Report on the implementation of community participation activities, submitted to the Head of the Provincial Dati I Provincial Office and the Director General of Forest Product Exploitation . ${ }^{1}$

Indeed, one of the new paradigms in forest management is said to be the empowerment of people around the forest in forest management, but in fact this is not new. In twards a Reform Minister Into the woods early and Plantation has mene Blocking Reception Menhutbun decision No. 1998 dated 7 Oktobet 677 / kpts II / 1998 on Forest Community were subsequently replaced by Decree Into the forest 's number: 31 / Kpts-II / 2001, dated 12 Pebru ari 2001 on Implementation of forest community. What is meant by the Forest Society here is forest country with the management system without disturbing the main function, with the goal of the member $\mathrm{d}$ Sifter an local communities in managing forests, while preserving the function of the forest $\mathrm{d}$ an environment in order to improve their welfare.

The scope of the implementation of community forestry covers the regulation of duties and functions as well as the responsibilities of the government, regional government and the community in aspects of determining areas for management, community preparation, licensing, management and control. According to Minister of Into the woods late the management area of forest community is the area of forest that is:

a. Become a source of livelihood for the local community.

b. Has the potential to be managed by the local community.

The determination of the area of community forest management is carried out through an inventory and identification by the district / city government whether it is appropriate for the local community in the surrounding forest area. The inventory and identification activities carried out cover the following aspects:

(1) Forest resources, especially timber potential, non-timber forest product potential, tourism potential, environmental service potential, state of land use, land potential.

(2) The social economy of the local community, especially livelihoods / sources of income, community history, level of welfare, land ownership. ${ }^{2}$

The results of the inventory and identification is further proposed Regents / Mayors for zoning management of forest community to the Minister of Into the woods late to the Governor to include a map of the area management, local community data and the potential area of forest. If the proposal is accepted, the Minister of Forestry shall determine the community forest management area by issuing a decree. Government, local government and the community to prepare the community is an effort to improve the local community institutions within the manager 's forest community with a marked formation of groups that have:

a. Internal group rules that are binding in decision making, conflict resolution and other rules in managing an organization.

b. The rules in community forest management are in accordance with the applicable laws and regulations .

c. Recognition from the community through the Village / Lurah Head.

d. Planned location and size of work area and duration of management.

Whereas the rules of community forest management include the arrangement of work area arrangement, preparation of management plans, utilization, rehabilitation, protection, as well as rights and obligations. For the determination of the location plan and the size of the work area as well as the duration of management carried

\footnotetext{
${ }^{1}$ ibid

${ }^{2}$ https://www.kompasiana.com/dikaeka/552a0cbff17e61d74fd623e0/telaah-s abbreviated- arti- forestry- social-and- kehforest- masyara kat . B ahwa Westoby, a forestry expert for the first ka Linya in 1968 had used the term Social Forestry ( Social Forestry ) in one of the forestry development strategy. According to Westoby, Social Forestry ( Social Forestry) is an approach to forestry development that has the aim of producing forest benefits for the protection and recreation of the community (Tewari, 1983). Meanwhile FAO in 1978 introduced the term Community Forestry $(C F)$ to describe all kinds of conditions involving local residents in forestry development activities.
} 
out in a participatory manner by the district / city government together with the local community by showing the ability of the group, the potential of land and forest and technical considerations from the agency to the local forest, the results of the determination of the plans This was then made in writing as an agreement between the regency / city government and local community groups .

In the reform era, the demand to carry out forestry reform is one of the issues that has received enough attention. One of these demands was to reform various laws - an invitation to the forest 's including provisions essentially alone on January 27, 1999 has been issued Government Regulation No. 6 of 1999 (LN 1999 No. 13) concerning forest exploitation and collection of forest products .

With the stipulation of this Government Regulation, Government Regulation No. 21 of 1970 jo. Government Regulation No. 181975 on concessions in forests and collection of the results of forest and Government Regulation No.7 of 1990 on Concession of Forest Plant industridinyat will no longer apply.

But as a note be added that government regulation is still referring to Act - Act Into the woods late that he ma namely Law - Law No. 5 of 1967.

After this followed in undangkannya Act - Act No. 41 of 1999 concerning forestry. When this Law comes into force, it is declared invalid:

1. Boschordonnantie java en Madoera 1927, Staatblad Tah un 1947 as amended by staatblad Year 1931 No.168 was recently changed to Staatblad Year 1934 No. 63.

2. Law - Law No. 5 of 1967 concerning the provision - basic provisions to the forest 's (Ln 1967 no. 8 TLN. 2823).

Invite constitution the easel in the legal basis the new policy with regard to the management of forests in Indonesia despite of various orga nsisasi civil society and Non-Governmental Citizens (NGOs) do not appreciate the actual content of the law - this law notwithstanding $b$ erubah but provisions essentially not much different from Law No. 5 of 1967.

Empowerment of the local community in and or around the forest are efforts made in order to improve the ability and independence of the community, because the community is a social community unit based on livelihoods that depend on the forest, welfare, attachment to housing and regulating the order of life together in institutional containers.

Resources Forest seb agai life support systems need to be managed and maintained its existence for the greater welfare of ra kyat equal and sustainable. Management of forests, as mandated in Law No. 41 of 1999 on Into the woods late he rahkan the realization of the management of forests sustainable then by regulation of the Minister Into the forest 's number P.01 / Me Nhut-II / 2004 dated July 12, 2004 on the Empowerment of local communities in and or around forests in the context of Social Forestry (SF).

It above, is a resource management system of forest in the area of forest the State and or forest rights, yan $g$ give an opportunity to the public setemp at as a principal or primary partners in order to improve social forestry is a reference program policy and community development activities that will come, and as a line to improve existing community empowerment programs and activities whose basic principles include:

a) The creation of an atmosphere or climate that allows the development of the potential and power possessed by the community.

b) Strengthen the potential or power possessed by the community.

c) Protect the community through taking sides with the community to prevent the effects of unfair competition. ${ }^{1}$

Social forestry is implemented based on forest management in line with community empowerment by taking into account the principles; benefits and le stari, self-help, togetherness and partnership, inter-sectoral integration, gradual, sustainable, locally specific and additive, with the following guidelines:

a. Does not change the status and function of forest areas .

b. Does not give ownership of the area huta $n$, except the right to use the resource forest

c. Not partial, but forest management is carried out in full.

b. Then in the development of social forestry through the main strategies, namely:

1) Manage ka wasan is a series of preconditions that sealed ukan to support the implementation of social forestry activities in order to optimize resource utilization of forest .

2) Institutional management is a series of efforts in the context of optimizing the implementation of social forestry through strengthening the organization, establishing regulations and increasing the capacity of human resources.

3) Business management is a series of activities that support the growth and development of businesses in social forestry work areas through partnerships with equal rights and responsibilities.

In social forestry, various parties play roles such as the government, provincial government, district / city government, non-governmental organizations, business entities, universities, community institutions and

${ }^{1}$ Ibid. 
international organizations. The role of the parties is intended to synergize the roles of various related parties in accordance with their respective duties and functions in the context of community empowerment.

AJ Leslie, who wrote the preface to his book westudy the propuse of forest-follies of development (1987), has actually been managing forests for centuries to respond to certain needs with the understanding that well managed forests can meet those needs in a sustainable manner as long as they are needed it's still there. So, all forms of forest management that improve the people are indeed broader in understanding compared to forest management which is solely a source of commercial products and services, in my opinion what should be in social forestry is forest management that benefits communities with weak economic and political positions .

Leslie's explanation emphasized that local people must have access and control over forest resources, only according to him local people are unable to voice what they really need from the forest both economically and politically.

Then William R. Burch (1992) with his opinion states; long before Europeans understood forest management in Asian communities to meet the needs of village communities and to integrate with social values and reflection in the works of those communities, those who use and protect forests ( forest management ) respect nature with gratitude, full of majesty in its unity.

\section{V . Assessing Against Per anserta Society and Holders g HPH da lam Function Preservation Forests}

As is known, Law No. 41/1999 concerning Forests is one of several legislation produced during the transitional government under President BJ. Habibie. This Act was born as an answer to the existence of Law No. 5 of 1967 concerning Basic Provisions to Forests which are considered to be no longer in accordance with the principles of control and management of forests and guidelines for the development of the situation.

With the enactment of Law N o. 41 Year 1999, there will soon be several implementing regulations in the form of Government Regulations and other implementation provisions. There are at least 19 articles of this Law which still require implementing regulations which are submitted to the Central Government. ${ }^{1}$ Some implementing regulations have so far been made, but some others still use the implementing rules of the old Forest Law

Some implementing regulations for Law N o. 41/1999 issued by the Government include:

1. Republic of Indonesia Government Regulation No. 6 of 1999 concerning Forest Exploitation and Collection of Forest Products in Production Forests

2. Republic of Indonesia Government Regulation No. 7 of 1999 concerning Preservation of Plants and Animals

3. Republic of Indonesia Government Regulation No. 8 of 1999 concerning Utilization of Wild Plants and Animals

4. Minister of Forestry and Plantation Decree No. 602 / Kpts-II / 1998 jo. No. 622 / Kpts-II / 1999 concerning AMDAL, UKL and UPL Forest and Plantation Development

5. Minister of Forestry and Plantation Decree No. 309 / Kpts-II / 1999 on Silviculture System and plant rotation in the Management of Forest Production.

By the most of the implementing provisions have not managed Refresh the implementation of the provisions of the Act Into the woods an old remains in effect throughout not be declared to be revoked or otherwise inappropriate.

Both when it was still in the form of a draft and until it was passed into law, the existence of Law No. 41 Year 1999 is never silent from a series of criticisms. Even the Law that was born at the end of BJ's administration. Habibie was the most among NGOs (Non Government Organization) judged not over me rang just change the title of the Act Into the woods an old one. This means that there is no fundamental change compared to the previous Forest Law . ${ }^{2}$

Various criticisms and criticisms have surfaced as a form of community mistrust in forest development policies that are still considered against the current reforms. Because the role of the Government in the management of forests are regulated in Law Into the woods late yan new g deemed to be too large. Even the Forest Law is considered as evidence of the government's arrogance in developing the forest sector . As proposed by the Coalition for Democracy Natural Resources (KUDETA) that U U Into the woods late ma does show the arrogance of power that is too excessive.

The accusation as to what was made was based on the nature of the policy that still uses a centralized pattern. As a result, state intervention in the management of the sector into forests has become very large . In addition, the policy is still too sectoral digunakanpun sehin gga can cause bad accesses on the lives of local communities around the forest, go KUDETA through a petition signed by 126 community groups observer of forest Ind onesia. As a result often happens, compartmentalization and overlap of its authority in the

\footnotetext{
${ }^{1}$ See: Post New Order Environment and Natural Resources (Potential and Hope for Good Environmental Governance) , published by ICEL (Indonesian Center for Environmental Law, 1999.

${ }^{2}$ Moh. Jeweler. 2013. Judgment of the New Forestry Law, in the Forestry Magazine . Jakarta: Department of Defense
} 
management of natural resources in the field of the departments in charge of the SDA . 1

In the day before it was enacted, the Government actually had received many inputs from various parties to revise the old Forest Law. But s epertinya with the enactment of Law Into the forest 's new, these inputs are not diakom odasi well by the government.

According to vote ICEL (Indonesian Center for Environmental Law), ${ }^{2}$ the recognition as mentioned above is very proud, considering that the recognition of indigenous and tribal peoples should only be carried out by the indigenous and tribal peoples themselves (growing from below), and not by the state represented by the government. Thus it is clear that in Law No. 41/1999 there is no adequate place for the sovereignty of indigenous peoples over their territory and wealth.

The old concept as contained in Unang Law No. 5 of 1967 fully adopted or absolutely no significant changes. Even according to Noer Fauzi ${ }^{3}[41]$, Chairperson of the Agency for the Implementation of the Agrarian Reform Consortium (KPA) stated that the Secondary Law of the Customary Law Community is under government regulation. The sentence " confession" as contained in the Law of the Act, is a ploy of words for a real purpose, namely restriction (if you don't want to be called oppression).

A series of facts concerning the legal status of the Customary Law Community in the field of Forestry cannot be released in relation to the concept of the State's Right to Control. There is no concept of political law ( political legal concept) that is the most influential in the matter of forest today and is as influential as the concept of the Right to Control from the State (HMN). HMN is the highest right that is imposed on land more than any rights.

Law Into formulator $h$ utan an apparently basing ri in Article 33 of the 1945 Constitution, paragraph 3 which states that: " the Earth's water and natural resources contained therein controlled by ne because for the greatest prosperity of the people" . In the various regulations, including the To field of forest late, HMN yes ng most dominant and problematic is the right held by the central government to define and regulate legal relations between oran $g$ those with land and natural resources, including forests .

In this concept there is an excessive belief that the central government as the holder and organizer of HMN is wise. The state is personified as an embodiment of the power of the people. It was never imagined that the government could become an autonomous structure and / or tool of the interests of the financiers and break away an ethical necessity " as much as the prosperity of the people, as had been practiced neatly during the New Order.

With the basic premise that the issue of natural resource management is a political problem, political reform is the basis for reform in the field of natural resource management and the environment. The reforms carried out must be able to answer all the main problems in forest management, for example policies regarding the reallocation and redistribution of forest resources more equitably. This allocation must place the community on par with other stakeholders .

Consequently, a more comprehensive, comprehensive and comprehensive form of legal protection and respect is needed to meet the needs of indigenous groups to guarantee the control of the forests that support them. To realize what it aspired $\mathrm{p}$ erlu changes are the views and political attitudes are more respectful of the Right to Self-Determination Send envy ( self determination ) of the community groups.

In addition, to support policies in forest management during the future, it must contain the main prerequisites, including:

1. Decentralization and deconcentration of forest (resource ) management between the central and regional governments.

2. Cooperation (partnership ) in the management of forest resources between the people and the government based on the principles of justice, sustainability, democracy and transparency.

3. Changing, revising or revoking a number of policies relating to the management and control of natural resources into policies that are explicitly in favor of the community.

4. Stronger supervision (control) of the people to drive the decision making process;

5. Comprehensive management that eliminates sectoral approaches in natural resource management (forests )

6. Balance between exploitation and conservation of natural resources and the environment

7. Justice for the people (partisanship) in accessing and utilizing natural resources. ${ }^{4}$

Perhaps only with these requirements, community participation in preserving the functions of forests in their regions can run well and optimally. Without a change in the vision and paradigm of forest management as stated above, the " climate" of forest management will remain shackled by an order that in fact is never the slightest fully enjoyed by the community.

\footnotetext{
${ }^{1}$ Ibid.

${ }^{2}$ Sentot Setyasiswanto, RUUK of the Habibie Order, in the Forestry Magazine without a year published.

${ }^{3}$ Post-New Order Environment and Natural Resources, Highlights for the New Government as a result of the 1999 General Election, published by ICEL 1999, p. 27.

${ }^{4}$ Itan, 2003. Towards a New Paradig of Management of Natural Resources, Paper on a Limited Discussion on Forest Problems in Central Kalimantan, carried out by the Central I Regional Forestry Office of Central Kalimantan and UNPAR. P. 2.
} 
As for the participation of HPH entrepreneurs themselves in forest preservation, based on the applicable legal provisions, it is actually sufficient to optimize their roles and participation, but the implementation in the field is often not as expected. There are at least three groups of HPH entrepreneurs in addressing their role in forest conservation :

1. Those who just want to obey the rules (are formalities)

2. Those who just want to reduce the possibility of demand

3. Those who consciously wanted to participate in the realization of development of forest sustainable

Although the above sequence does not fully apply to all HPH entrepreneurs, it can be said that most or in general follow the order and this will be more clearly seen if we read the impact control documents (AMDAL) submitted by HPH entrepreneurs to the Government, especially in the Objectives and Study Sections section where explicitly the first motivation above is placed at the top while sometimes the third order is forgotten.

In order to achieve insightful development in the forest sector, the above motivational sequence is certainly not ideal, because what is best is precisely the opposite order, where environmental awareness should come first from the HPH entrepreneurs as actors of activities, so that the government and the community simply do guidance and supervision.

\section{VI . Closing Note}

That the management of powers as stated in Law No. 41 of 1999 has progressed because regional authority over forest management is wider than the previous law. This is a manifestation of the increasingly greater authority given to the region to manage the forests in its area. In the management of the forest, there is a concern for the people and the management of the forest and the environment has been integrated. It $\mathrm{i}$ ni become an important part in the efforts for members of the Dayak an huta $n$ accordance with the principles of the management of natural resources are limited.

The community's rights in managing forests are protected and recognized so that forest management becomes part of the development of indigenous peoples. This condition is a proof of the respect of indigenous peoples for forests that are already dependent on forests for their potential for life. For it in order to involve the public on the responsibilities and benefits of management huta $\mathrm{n}$, then the public about enforced Dayak late to get involved in the management of the forest. The empowerment of the community by always taking into account the integrative potential of the forest and its future development as a limited natural resource.

For this ba hwa role Concession rights holders Forests are very important in preserving the forest. It is the logging concessions that have great potential to exploit forests because of the complete infrastructure for this. Concession holders were members activities Dayak an huta $\mathrm{n}$ must consider the condition of the forest , especially for the future. In this case, the integration of handling the problems that arise as a result of exploitation of forests is still not optimal. There are regional authorities which have not been properly implemented due to various regional limitations that are based on the limitations of human resources .

In connection with the above, it is necessary to have a regulation that clearly explains the concept of forest management according to Law No. 41 of 1999, so that forest management is truly realized and can bring benefits to the environment and surrounding communities. For this reason, it is also necessary to clarify the authority regarding forest management between regencies / cities and provinces. This is to prevent the overlapping of the exercise of authority held by the two institutions specifically with the existence of regional autonomy.

Likewise, there needs to be a more concrete affirmation in the legislation regarding the rights of indigenous peoples to forests so that their involvement in forest management for Dayak and community members becomes evident. This is to prevent the continued domination of HPH holders over the forest. There is a need for more concrete clarification regarding the implementation of government and provincial government and district / city government implementation by implementing empowerment properly. Here a more comprehensive arrangement is needed for regulations relating to the issuance of HPH permits, which are located across regencies / cities where prior to issuance of permits, recommendations from the Regent / Mayor are required. In addition to the fundamental is the regulation that lays $\mathrm{k}$ ebijaksanaan that regulate more clearly the implementation of the manager 's forests are in line with the Law number: 322004 T Entang Pemerint ah Da erah with all amendments thereto.

\section{REFERENCES}

Ali Akbar. 1999. Safeguarding the Wisdom of Lukal Indigenous Peoples . Pontianak: Institution of Dayak Society Study .

Almar, Idris Sarong. 1993. Penguk uhan Forests and Legal Aspects (A juridical analysis) Part I . (Material Penataran) Jakarta: Ministry of Into the woods late.

J. Kusni. 2000. Lessons From Dayak Communities . Pontianak: Institute of Dayak ologi.

Koesnadi Hardjasoemantri. 2000. Environmental Law . Ed content 7. Yogyakarta: Gadjah Mada University Press. Lampah D. Sihite. 2000. Biodiversity in Indonesia. Pontianak: Institute for Dayak Communities , 
Sarbaini. 1999. The Socio-Cultural Approach of Indigenous Peoples Welcomes a United Indonesia. Solo: Panepen Mukti.

Suwiryo Ismail, 1999. " Strengthening the Role of Communities in the Management of Natural Resources and the Environment in the Regions" 2Paper Presented at the Training on Preparation of the Environmental Impact Management Program in collaboration with ProLH-BAPEDAL, Jakarta Dec. 1999

Sukamdani. 1988. Indigenous Peoples in the Legal Anthropology Perspective. Jakarta: Indonesian University. Wiyono ,. " Management of Forest Resources in the Context of Regional Autonomy " . 2001. AruPA website. 